Am. J. Trop. Med. Hyg., 44(2), 1991, pp. 205-217 (90-165)

Copyright $\odot 1991$ by The American Society of Tropical Medicine and Hyeiene

\title{
ANDEAN LEISHMANIASIS IN ECUADOR CAUSED BY INFECTION WITH LEISHMANIA MEXICANA AND \\ L. MAJOR-LIKE PARASITES
}

YOSHIHISA HASHIGUCHI, EDUARDO A. GOMEZ, VICENTA V. DE CORONEL, TATSUYUKI MIMORI, MASATO KAWABATA, MASATO FURUYA, SHIGEO NONAKA, HIROYUKI TAKAOKA, J. BRUCE ALEXANDER, AIDA M. QUIZHPE, GABRIEL GRIMALDI JR., RICHARD D. KREUTZER, AND ROBERT B. TESH

Kochi Medical School, Nakoku, Kochi, Japan; Facultad de Medicina, Universidad Catolica Santiago de Guayaquil, Guayaquil, Ecuador; Instituto Nacional de Higiene y Medicina Tropical, Guayaquil, Ecuador; Kumamoto University School of Medicine, Kimamoto, Japan; Nihon University School of Medicine, Tokyo, Japan; Institute for Laboratory Animals, Kochi Medical School, Kochi, Japan; Nagasaki University School of Medicine, Nagasaki, Japan; Oita Medical College, Hazama, Oita, Japan; Central Florida Research and Education Center, Sanford. Florida, USA; Hospital Cantonal Paute, Paute, Azuay, Ecuador; Institute Oswaldo Cruz, Rio de Janeiro, Brazil; Youngstown State University, Youngstown, Ohio, USA; Yale University School of Medicine, New Haven, Connecticut, USA

Abstract. Between 1986 and 1988, epidemiologic studies were carried out in a small rural community in an Andean region of Ecuador, where cutaneous leishmaniasis is highly endemic. A total of 25 human cases, positive for Leishmania parasites by culture and/or smear, were examined. Fourteen of the cases were in infants less than one year of age, suggesting intradomiciliary transmission of the disease. Clinically, many of these cases were similar to descriptions of "uta," a form of cutaneous leishmaniasis which occurs in Andean regions of Peru and is reportedly caused by $L$. peruviana. Of the 11 positive cultures obtained from human cases in the present study, eight were identified by molecular characterization as $L$. mexicana and three were identified as $L$. major-like. Two additional isolates of $L$. mexicana were also made from an infected dog and from a sand fly, Lutzomyia ayacuchensis, living in the region, thus implicating the latter species as possible reservoir and vector, respectively, of $L$. mexicana in this highland community. The significance and validity of recent isolates of $L$. major-like parasites from the New World are also discussed.

Cutaneous and mucocutaneous leishmaniasis are endemic in Ecuador; the disease occurs in both lowland and Andean regions of the country. ${ }^{1,} 2$ To date, five different species of the parasite (Leishmania braziliensis, L. panamensis, $L$. guyanensis, $L$. mexicana and $L$. amazonensis) have been isolated from Ecuadorian patients with the disease. ${ }^{3.4}$ In a previous paper we reported Leishmania isolates made from humans and wild mammals living in warm, humid lowland areas on the Pacific Coast of Ecuador. ${ }^{3}$ Because of reports of leishmaniasis from other regions of the country, we decided to investigate the etiology of the disease in a representative Andean focus. The present paper describes the results of this study and reports human disease in highland regions of Ecuador caused by $L$. mexicana and an unusual parasite closely related to $L$. major.

MATERIALS AND METHODS

\section{Description of the study area}

The investigation was carried out in and around Canton Paute, a small rural community of about
2,000 people, which is situated at an altitude of between 2, 300 and 2, 500 meters above sea level $\left(2^{\circ} 46^{\prime} 5,78^{\circ} 45^{\prime} \mathrm{W}\right)$ in Azuay Province, in the Central Andean region of Ecuador (Fig. 1). The study area is surrounded by rocky slopes, which are covered with alpine vegetation consisting of grasses, low shrubs and Agave (Fig. 2A-D). Tree cover is restricted to the lower mountain slopes and consists of sparse Eucalyptus groves. The climate during the dry season (May to October) is moderate, with temperatures during the day reaching $15-25^{\circ} \mathrm{C}$ but dropping to as low as $6^{\circ} \mathrm{C}$ at night because of the altitude. During the rainy season (November to April), the humidity and temperature are somewhat higher.

The outdoor activities of the local inhabitants are confined mainly to daylight hours because of the low nocturnal temperatures; consequently, the people do not usually enter the surrounding countryside for hunting, work or other purposes after dark. Crops raised in the area include potatoes, corn, beans, lentils and lettuce; domestic 


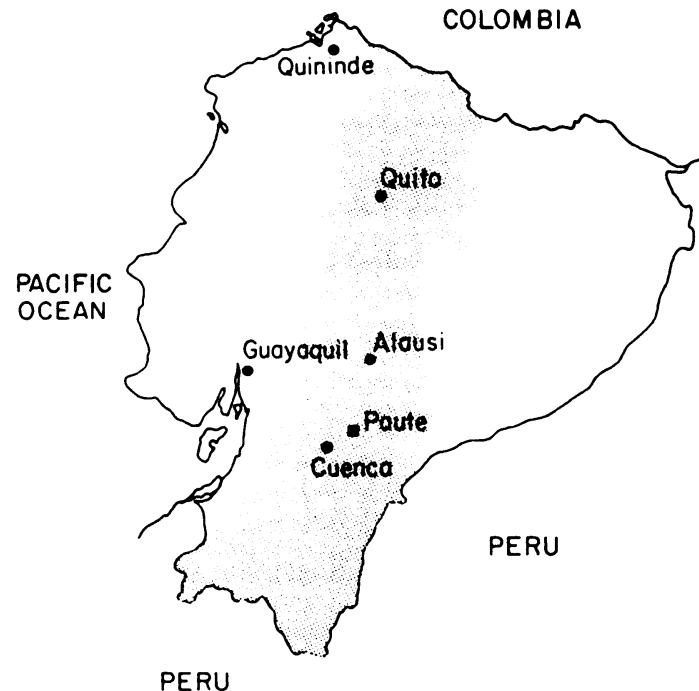

FIGURE 1. Map of the Republic of Ecuador, showing location of the study area (Paute), principal cities, and other localities where $L$. mexicana or $L$. majorlike parasites were isolated. Shaded area on map indicates the Andean region of the country and elevations $\geq 1,000$ meters above sea level.

animals present in the community are dogs, guinea pigs, rabbits, cattle, horses and chickens. The wild mammal fauna of the area is somewhat depauperate and consists of mainly rats, mice, rabbits, opossums, mustelids and wild canines.

\section{Sand fly collections}

Collections of phlebotomine sand flies were made between the hours of 18:00 and 21:00, by aspirating the insects as they came to bite human volunteers sitting around the rocks and animal burrows where resting sand flies had been encountered during the day. The collection techniques were described in detail in two earlier publications. 5,6

\section{Examination of patients with dermal lesions}

Laboratory and clinical examinations of the subjects were performed in the town at the Hospital Cantonal Paute. All necessary information on subjects was recorded on registration cards prepared by the authors. Specimens for smear and culture were taken from persons with suspected leishmanial ulcerous lesions visiting the hospital. House visits were also made in the community to search for unreported leishmaniasis cases; subjects with suspicious dermal lesions were taken to the hospital for further detailed examinations.
Isolation of parasites

In order to identify the causative agent(s) of cutaneous leishmaniasis in the area, an attempt was made to isolate Leishmania parasites from human cases, domestic dogs and potential sand fly vectors. The dogs and sand flies were obtained from the Don Boscos housing project in Paute and from three surrounding localities, Yumacay, Cenacuro and Tutucan, situated 1 to $3 \mathrm{~km}$ from the town (Fig. 2C). Material for culture was collected by syringe aspiration from cutaneous ulcers of human patients and from the livers of dogs; this material was inoculated directly into tubes of blood agar. Phlebotomine sand flies were captured, as described above, and then dissected and examined for the presence of promastigotes; if positive, the gut contents were aspirated into a syringe and inoculated into the nose of a Syrian hamster. If local swelling or an ulcerative lesion subsequently developed at the inoculation site, the affected tissue was biopsied, triturated and then cultured in tubes of blood agar.

The medium used for culture was slightly modified from that described by Walton and others. ${ }^{7}$ It contained $40 \mathrm{~g}$ of Difco blood agar base (Difco Laboratories, Detroit, MI), 1,000 ml of distilled water and $20 \%$ defibrinated rabbit blood. Two $\mathrm{ml}$ of melted medium were poured into glass culture tubes, and the tubes were sealed with rubber caps. These blood agar slants were left at room temperature for several hours to allow formation of condensation fluid, and then were stored at $4^{\circ} \mathrm{C}$ until used. Prior to use, an overlay of sterile saline $(0.9 \%)$ was added to each tube. Two drops of a $20 \%$ gentamycin solution were sometimes added to combat bacterial contamination.

\section{Parasite characterization}

Most of the Leishmania isolates made during this study were characterized by three different molecular techniques: isozyme electrophoresis, ${ }^{8-10}$ indirect radioimmune assay using specific monoclonal antibodies, ${ }^{11-17}$ and restriction endonuclease fragment patterns of $\mathrm{kDNA}{ }^{16,18,19}$ These procedures are done routinely in our laboratories (G.G., Jr. and R.D.K.) for the identification of Leishmania parasites; the techniques have been described in detail in previous publications. ${ }^{3,8-19}$ 

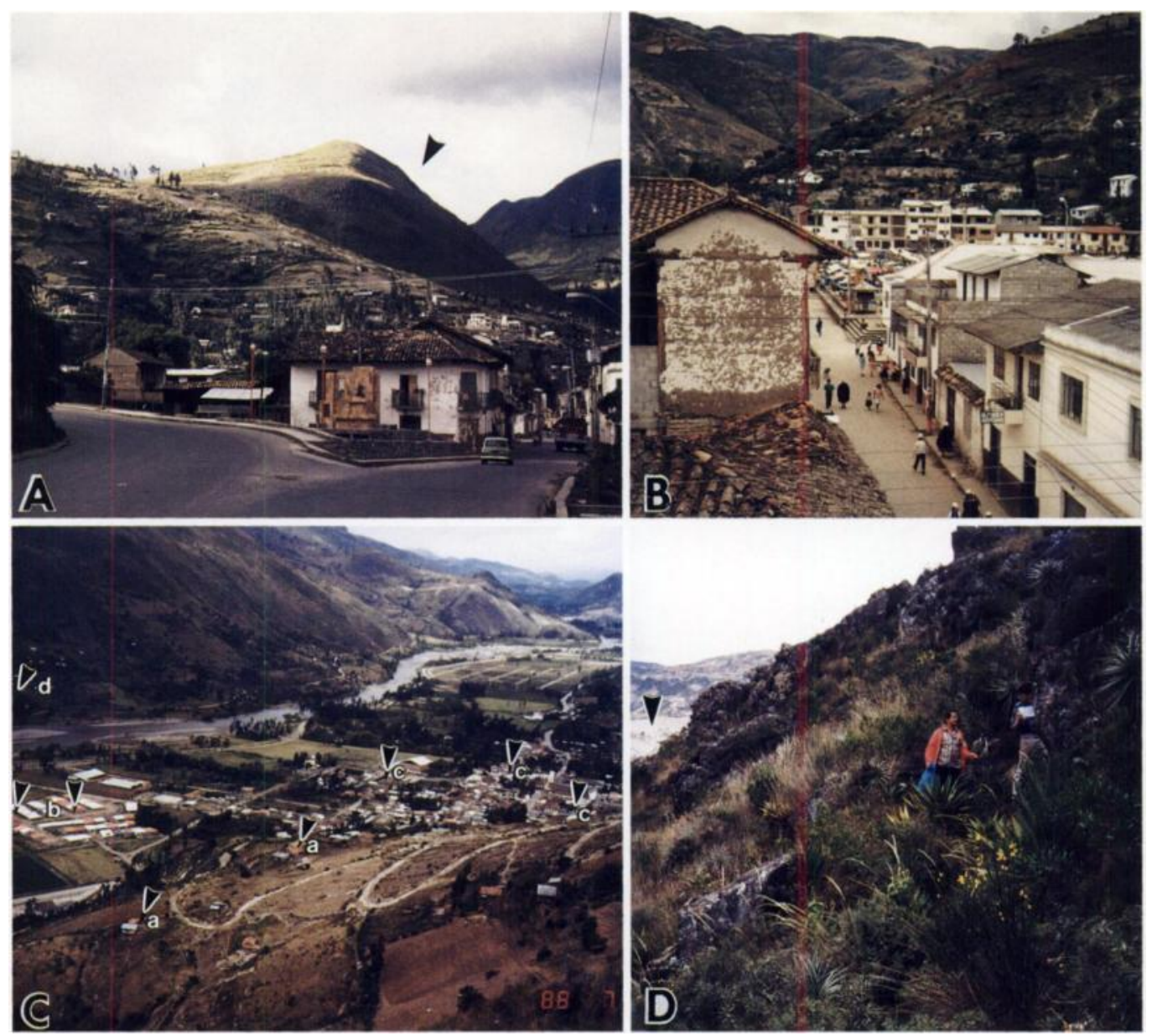

Fioure 2. General landscape of the study area (Canton Paute). A. Entrance to the town: Yumacay mountain where the sand flies were collected is indicated by arrow. B. Center and outskirts of Paute, showing human dwellings. C. View of Paute from Yumacay mountain, showing the high rocky hills surrounding the town. Arrows indicate the sites where positive leishmaniasis cases lived; letters identify various sites in the community. $a=$ Yumacay, $b=$ Don Boscos, $c=$ Paute proper, $d=$ Tutucan. D. Ecologic features of Yumacay mountain illustrating low shrubs and rocky terrain above Paute.

\section{RESULTS}

\section{Clinical and epidemiologic studies}

As shown in Table 1, a total of 25 persons with active cutaneous leishmaniasis were identified; these subjects all had ulcerous lesions with abundant amastigotes present in smear specimens. No sex difference in the incidence of the disease was observed among this group of subjects: 13 were males and 15 were females. Interestingly, all of the subjects were children; their ages ranged from 3 months to 9 years. Fourteen of these children $(56 \%)$ were less than one year of age. None of the adults seen with dermal lesions were diagnosed as having Leishmania infection.

Most of the positive lesions ( $88 \%$ ) occurred on the face, with the remainder on the ear, arm and foot (Table 1). The localization of leishmanial lesions to these exposed sites is probably a reflection of the cool climate and the fact that most of the rest of the body is covered at night, particularly in small children. The number of lesions per person ranged from 1 to 9 ; only $24 \%$ of the cases had more than two lesions. Almost all of the subjects had small, localized lesions, measuring less than $5 \mathrm{~mm}$ in diameter (Figure 3B). 
TABLE 1

Clinical and parasitological findings in 25 human cases of cutaneous leishmaniasis seen in Paute, Department of Azuay, Ecuador between July 1986 and August 1988

\begin{tabular}{|c|c|c|c|c|c|c|c|}
\hline Age* & Sex & $\begin{array}{l}\text { Number } \\
\text { of lesions }\end{array}$ & Size of lesions ${ }^{* *}$ (number) & Site of lesions & $\begin{array}{c}\text { Dura- } \\
\text { tion } \\
\text { (months) }\end{array}$ & Smear" & Culture result" (identification) \\
\hline $4 Y$ & $\mathbf{M}$ & 1 & $5 \times 2$ & face & 5 & + & 0 \\
\hline $6 Y$ & $\mathbf{F}$ & 1 & $15 \times 10$ & face & 14 & + & + (L. major-like) \\
\hline $12 \mathrm{M}$ & $\mathbf{F}$ & 1 & $4 \times 4$ & face & 14 & + & 0 \\
\hline $3 \mathbf{M}$ & $\mathbf{F}$ & 2 & $5 \times 3,2 \times 2$ & face & 3 & + & 0 \\
\hline $5 Y$ & $\mathbf{F}$ & 1 & $3 \times 3$ & face & 7 & + & + (L. mexicana $)$ \\
\hline $7 \mathrm{M}$ & $\mathbf{F}$ & 1 & $5 \times 4$ & face & 3 & + & 0 \\
\hline $25 \mathrm{M}$ & $\mathbf{F}$ & 1 & $2 \times 2$ & face & 24 & + & 0 \\
\hline 39M & $\mathbf{F}$ & 2 & $3 \times 3(2)$ & face & 3 & + & 0 \\
\hline $12 \mathrm{M}$ & $\mathbf{M}$ & 2 & $3 \times 2,2 \times 2$ & face & 2 & + & 0 \\
\hline $20 \mathrm{M}$ & $\mathbf{F}$ & 4 & $\begin{array}{l}4 \times 3,3 \times 2 \\
2 \times 2(2)\end{array}$ & face & 6 & + & 0 \\
\hline $9 Y$ & $\mathbf{M}$ & 1 & $7 \times 5$ & foot & 4 & + & 0 \\
\hline $5 \mathrm{M}$ & $\mathbf{M}$ & 1 & $5 \times 5$ & arm & 3 & + & + (L. major-like) \\
\hline $5 Y$ & $\mathbf{M}$ & 2 & $5 \times 4,3 \times 2$ & ear, arm & 2 & + & 0 \\
\hline $5 M$ & $\mathbf{M}$ & 2 & $5 \times 4,4 \times 3$ & face & 4 & + & + (L. mexicana $)$ \\
\hline $10 \mathrm{M}$ & $\mathbf{M}$ & 2 & $3 \times 2,2 \times 2$ & face & 4 & + & 0 \\
\hline $9 Y$ & $\mathbf{M}$ & 1 & $2 \times 2$ & face & 3 & + & 0 \\
\hline $11 \mathrm{M}$ & $\mathbf{M}$ & 1 & $1 \times 2$ & face & 7 & + & + (L. mexicana) \\
\hline $11 \mathrm{M}$ & $\mathbf{F}$ & 1 & $3 \times 2$ & face & 9 & + & + (L. mexicana) \\
\hline $10 \mathrm{M}$ & $\mathbf{F}$ & 3 & $3 \times 3(3)$ & face & 8 & + & + (L. mexicana) \\
\hline $10 \mathrm{M}$ & $\mathbf{M}$ & 3 & $3 \times 2,2 \times 2(2)$ & face & 4 & + & 0 \\
\hline $10 \mathrm{M}$ & $\mathbf{M}$ & 4 & $\begin{array}{l}5 \times 5,2 \times 2 \\
1 \times 1(2)\end{array}$ & face & 4 & + & + (L. mexicana) \\
\hline $11 \mathrm{M}$ & $\mathbf{M}$ & 2 & $2 \times 2(2)$ & face & 9 & + & + (L. major-like) \\
\hline $5 \mathrm{M}$ & $\mathbf{M}$ & 1 & $3 \times 2$ & face & 4 & + & + (L. mexicana) \\
\hline $7 \mathbf{M}$ & $\mathbf{F}$ & 9 & $\begin{array}{l}5 \times 4,3 \times 3(2) \\
1 \times 1(6)\end{array}$ & face & 4 & + & 0 \\
\hline $9 M$ & $\mathbf{F}$ & 5 & $\begin{array}{l}4 \times 4,2 \times 2(20) \\
1 \times 1(2)\end{array}$ & face & 2 & + & $+($ L. mexicana $)$ \\
\hline
\end{tabular}

- $Y=$ years; $M=$ months.

- Size of lesion in $\mathrm{mm}$.

- Duration of disease at time patient was first seen.

" Positive smear or culture (+); Negative culture (0). Identification based on molecular characterization of isolates, a of isolates, as noted in text.

The incidence of new leishmaniasis cases in the community varied according to the time of year; the majority of subjects were infected during the rainy season (November to April). The duration of the disease was recorded as the time period between the earliest awareness of the infection and the date of first hospital examination (Table 1). This period varied in length from 2 to 24 months, although most of the lesions (88\%) were of less than 12 months duration. This time was undoubtedly influenced by the age of subject population, since many of the cases were in children less than 1 year of age. Parents of 3 infants (ages 3, 8 and 12 months) reported that the infections were noted shortly after birth at 3,30 and 15 days, respectively. The homes of these subjects were situated close to the rocky habitat (rock crevices) where sand flies were observed resting during the day and where the insects were collected from human bait at night. The proximity of sand flies to houses and the young age of many of the subjects suggest that these insects probably enter human dwellings at night to feed and that intradomiciliary transmission of the disease is occurring in Paute.

A total of 11 Leishmania isolates were made in Paute from the 25 human cases with amastigote-positive smears (Table 1). Three of these isolates were identified as $L$. major-like and eight were identified as $L$. mexicana (Tables 1 and 2 ). An effort was also made to isolate parasites from domestic dogs in the area. Two of 30 dogs (6.7\%) examined from Don Boscos and Yumacay were positive on smear for leishmanial infection; parasites cultured from one of these positive animals were identified as $L$. mexicana. All of the isolates were characterized by two or more of the molecular techniques described above. 


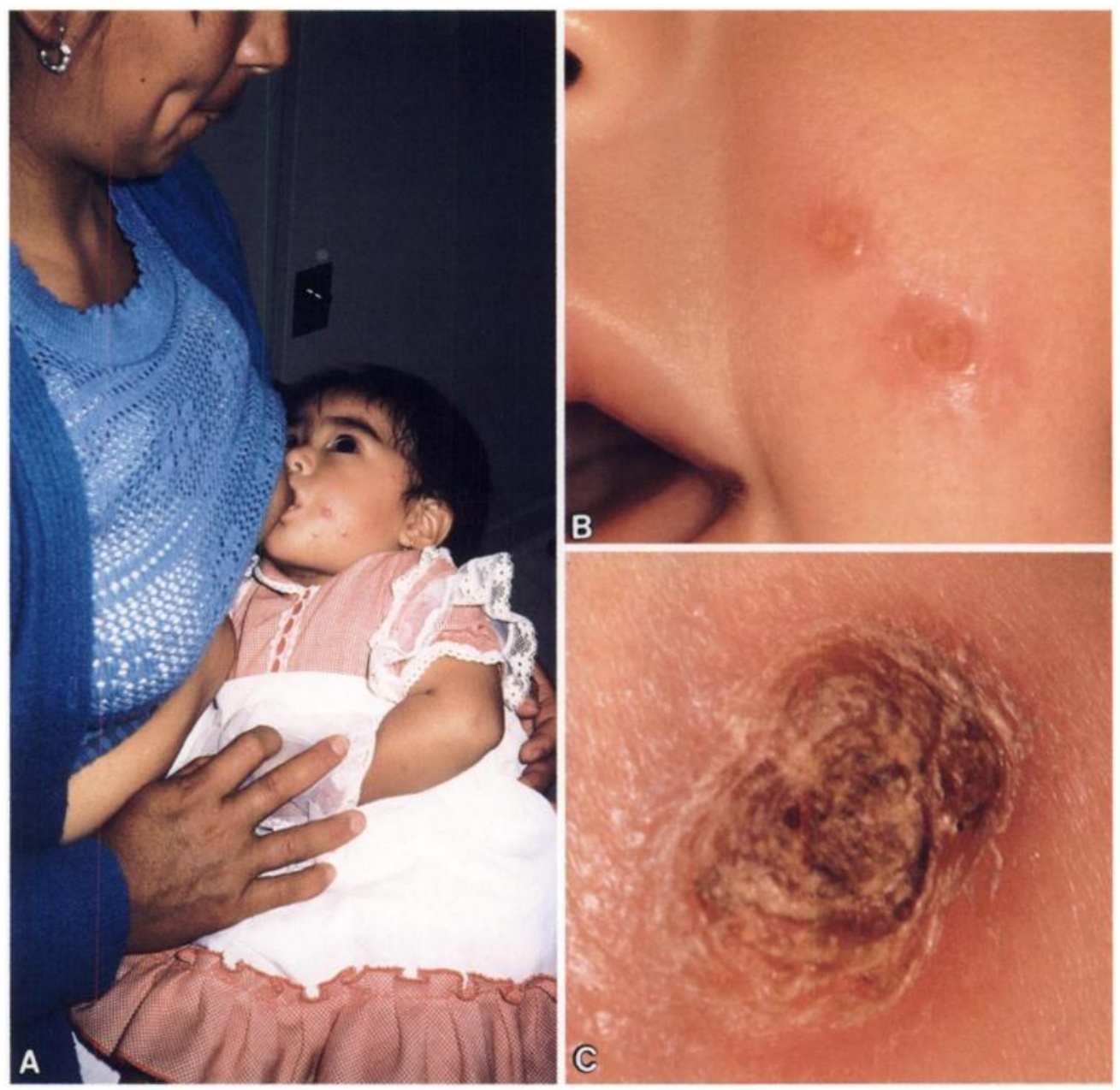

Figure 3. Representative lesions of cutaneous leishmaniasis patients in Paute. A 9-month old girl with 5 lesions $(4 \times 4,2 \times 2,2 \times 2,1 \times 1$ and $1 \times 1 \mathrm{~mm})$ of 2 months duration on her face. B. Two small lesions $(3$ $\times 2$ and $2 \times 2 \mathrm{~mm}$ ) on the face of a 10-month old boy. C. A somewhat larger lesion (15 $\times 10 \mathrm{~mm})$, on the face of an 11-month old male infant.

During other studies on the epidemiology of leishmaniasis in Ecuador, two additional isolates of $L$. mexicana and the $L$. major-like parasite were made from subjects living in Alausi, Department of Chimborazo, and Quininde, Department of Esmeraldas, respectively (Figure 1). Alausi is a highland community (elevation 2,500 meters), located about $80 \mathrm{~km}$ north of Paute; Quininde is situated in the Pacific lowlands. The latter two parasite strains were included with the eight $L$. mexicana and three other $L$. major-like human isolates from Paute in the comparative molecular studies described below. Both of the subjects from whom these strains were isolated had single, localized cutaneous lesions.
During 1988, a preliminary survey of the sand fly fauna of the Paute study area was made. Diurnal collections revealed the presence of two closely related species, Lutzomyia ayacuchensis, Caceres and Bianchi Galati and Lu. osornoi Ristorcelli and Van Ty. The former was more abundant in human bait collections. Two of $97(2.1 \%)$ $\mathrm{Lu}$. ayacuchensis collected at that time from $\mathrm{Yu}-$ macay and Cenacuro had promastigotes in their guts. ${ }^{6}$ Parasites were present in the anterior and posterior portions of the midgut but were not found in the hindgut, indicating that they were suprapylarian in their development. One of these samples was successfully cultured and subsequently identified as $L$. mexicana. These prelim- 
TABLE 2

Origin and identification of Leishmania reference strains and 15 isolates from Ecuador which were characterized by monoclonal antibodies ${ }^{1}$, isoenzyme $e^{2}$ and/or schizodeme $(k D N A)^{3}$ analyses in this study

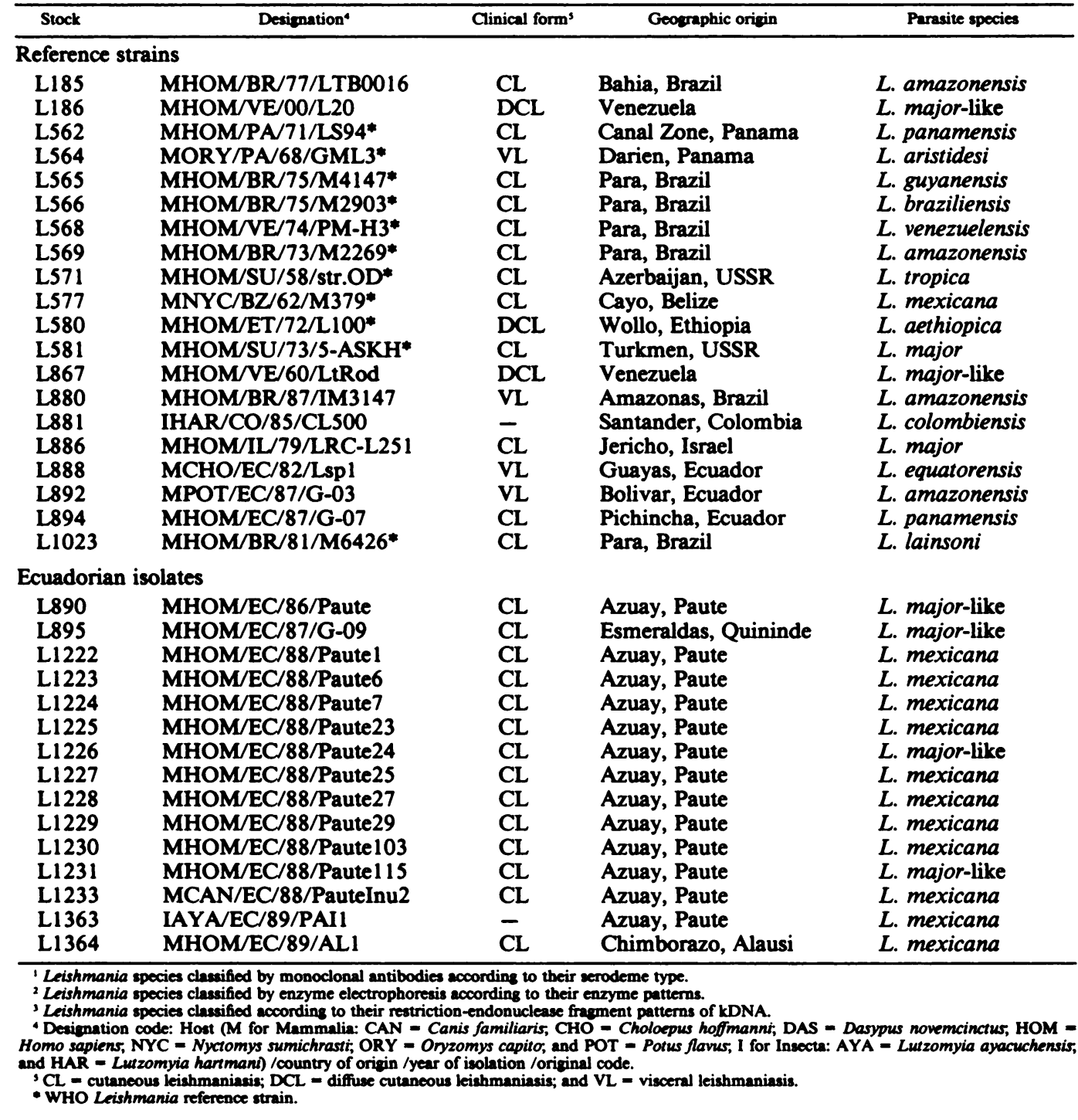

inary data suggested that $L u$. ayacuchensis might be a vector of this parasite in the Paute area. Accordingly, in September, 1988, a 13-month longitudinal study was initiated to determine the seasonal variation in Leishmania infection rates and the biting activity of $\mathbf{L u}$. ayacuchensis in Canton Paute. The results of this latter study were published elsewhere. 5.6 of 2,600 Lu. ayacuchensis collected from human bait over the 13-month period, $95(3.7 \%)$ were found to be naturally infected with promastigotes. Although these parasite-positive insects were not cultured, the promastigotes were always observed in the sand fly midgut, indicating that they were probably members of the mexicana complex.

\section{Laboratory studies}

Isoenzyme electrophoresis. Ten of the Paute isolates, (eight from humans and one each from an infected $\operatorname{dog}$ and a sand fly) and the single human isolate from Alausi had identical allo- 

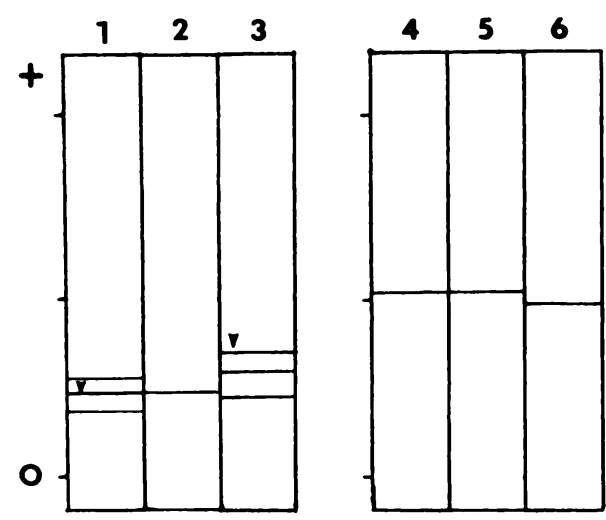

GPI

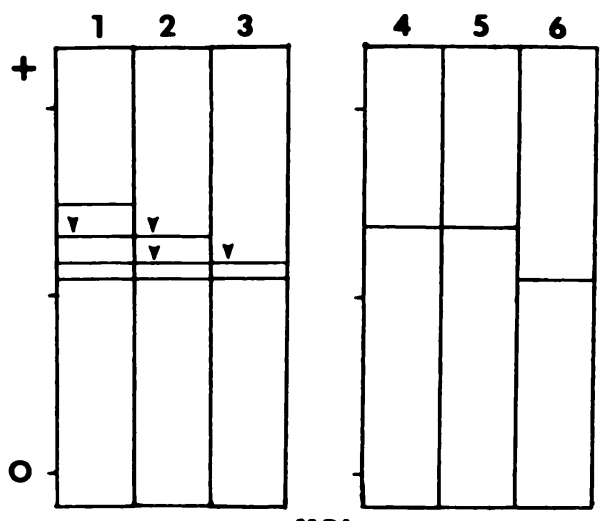

MPI

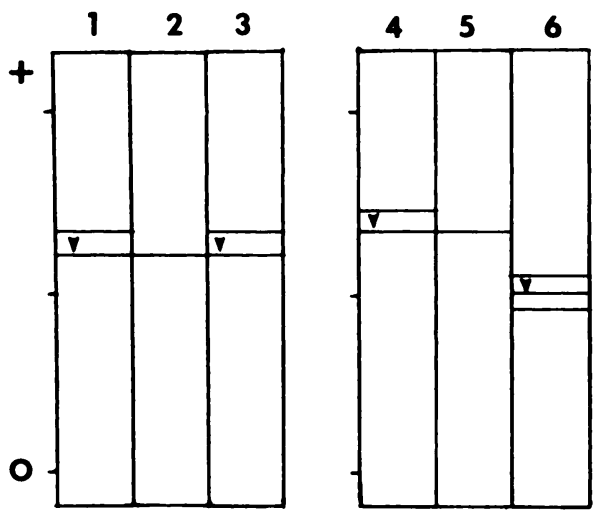

GPGDH

FIGURE 4. Diagrammatic representations of the electrophoretic patterns (allomorphs) of glucose phosphate isomerase (GPI), mannose phosphate isomerase (MPI) and 6-phosphogluconate dehydrogenase (6 PGDH), distinguishing the 2 groups of Ecuadorian isolates and showing the similarities in the enzyme profiles of each group with $L$. mexicana and $L$. major reference strains. Lane 1 represents the allomorphs of $72 L$. mexicana strains; lane 2 shows allomorphs of the Paute and Alausi $L$. mexicana strains listed in Table 2; lane 3 of 165 $L$. amazonensis strains; lane 4 of $69 \mathrm{~L}$. major strains; lane 5 of $L$. major-like strains L1231 from Paute, L895 from Quininde, and the reference strain L867 from Venezuela lane 6 of $54 \mathrm{~L}$. tropica isolates. 0 is origin. Anode is at the top of each diagram. The arrow identifies the most frequent allomorph.

morphs (bands of enzyme activity observed by electrophoresis); these enzyme electrophoretic profiles were similar to those possessed by the WHO $L$. mexicana reference strain (stock code L577 in Table 2) for the enzymes GPI, MPI, and 6 PGDH (Figure 4). The latter enzymes are useful in distinguishing most Leishmania ${ }^{10}$ and indicate that the aforementioned isolates were $L$. mexicana.

One of the remaining three human isolates from Paute (L1231), plus the single strain from a subject in Quininde (L895) were examined by isozyme electrophoresis. These two isolates were extremely homogeneous and had identical elec- trophoretic profiles for each of the enzymes tested (up to 20 enzymes). Their profiles were distinct from those of any of the WHO reference strains or from other stocks of the $L$. mexicana, $L$. braziliensis, and $L$. donovani complexes reported previouslys-10 for the same enzymes. In contrast, the enzyme electrophoretic profiles of these two isolates were similar to those possessed by $68 \mathrm{~L}$. major reference strains, including the WHO reference strains L581 and L886 (Figure 4). A similar profile was also produced by parasite strain L867 which was originally isolated from a case of diffuse cutaneous leishmaniasis (DCL) in Venezuela and was used in another 
TABLE 3

A comparison of the binding' of Leishmania species-specific monoclonal antibodies to reference strains and selected Leishmania isolates from Ecuador

\begin{tabular}{|c|c|c|c|c|c|c|c|c|c|c|c|c|c|}
\hline \multirow{2}{*}{$\begin{array}{l}\text { Stock } \\
\text { code }\end{array}$} & \multirow[b]{2}{*}{ Species $^{2}$} & \multicolumn{12}{|c|}{ Monoclonal antibodies' } \\
\hline & & M2 & $\overline{\mathbf{M} 3}$ & M7 & M8 & P9 & $\mathbf{v 1}$ & T1 & T2 & T3 & T4 & T8 & T10 \\
\hline \multicolumn{14}{|c|}{ Reference strains } \\
\hline L569 & L. amazonensis & 32.0 & 12.7 & 13.7 & 2.4 & 2.0 & 1.8 & 1.2 & 2.1 & 0.8 & 0.9 & 1.0 & 1.6 \\
\hline L564 & L. aristidesi & 26.9 & 1.4 & 0.8 & 1.6 & 1.4 & 1.0 & 1.4 & 1.8 & 1.4 & 1.6 & 1.3 & 0.9 \\
\hline L577 & L. mexicana & 1.6 & 1.8 & 26.2 & 32.9 & 1.6 & 1.2 & 1.5 & 7.3 & 7.7 & 1.2 & 4.4 & 1.0 \\
\hline L568 & L. venezuelensis & 1.2 & 1.0 & 0.8 & 1.2 & 2.0 & 7.4 & 3.6 & 5.2 & 10.4 & 1.6 & 2.3 & 1.1 \\
\hline L867 & L. major-like & 1.2 & 1.3 & 1.6 & 1.0 & 8.5 & 0.8 & 37.6 & 33.7 & 40.2 & 16.0 & 8.3 & 2.4 \\
\hline L568 & L. major & 1.2 & 1.5 & 2.1 & 2.4 & 1.5 & 1.7 & 38.4 & 34.8 & 41.0 & 17.7 & 12.3 & 2.2 \\
\hline L571 & L. tropica & 1.0 & 0.7 & 2.0 & 1.0 & 1.4 & 1.6 & 8.4 & 18.9 & 22.6 & 5.9 & 2.7 & 20.8 \\
\hline L580 & L. aethiopica & 1.0 & 1.2 & 1.6 & 1.2 & 1.6 & 1.3 & 3.6 & 7.6 & 16.9 & 1.1 & 1.3 & 1.0 \\
\hline \multicolumn{14}{|c|}{ Ecuador isolates ${ }^{4}$} \\
\hline L1222 & L. mexicana & 1.6 & 1.8 & 6.6 & 4.4 & 1.9 & 1.6 & 12.0 & 19.3 & 26.4 & 6.3 & 6.8 & 1.9 \\
\hline L1233 & L. mexicana & 2.1 & 2.0 & 1.8 & 3.9 & 2.1 & 1.8 & 14.2 & 23.5 & 31.5 & 9.7 & 6.8 & 1.8 \\
\hline L1224 & L. mexicana & 1.7 & 1.7 & 1.8 & 4.3 & 1.8 & 1.7 & 8.7 & 18.3 & 24.4 & 5.3 & 6.1 & 1.4 \\
\hline L1363 & L. mexicana & 1.0 & 1.6 & 3.4 & 5.2 & 1.4 & 1.1 & 22.3 & 19.6 & 24.8 & 10.3 & 5.6 & 1.4 \\
\hline L1364 & L. mexicana & 1.5 & 2.0 & 2.4 & 4.2 & 1.5 & 1.6 & 17.7 & 23.6 & 26.7 & 5.6 & 4.6 & 1.2 \\
\hline L890 & L. major-like & 2.6 & 2.3 & 1.8 & 1.2 & 6.4 & 1.8 & 26.1 & 38.0 & 42.3 & 10.0 & 7.5 & 1.6 \\
\hline L895 & L. major-like & 1.7 & 1.2 & 1.0 & 1.2 & 5.8 & 1.3 & 36.9 & 13.6 & 9.8 & 7.2 & 5.0 & 0.8 \\
\hline L1226 & L. major-like & 1.0 & 0.8 & 1.0 & 1.6 & 4.5 & 1.0 & 8.2 & 18.2 & 25.0 & 3.6 & 4.8 & 1.0 \\
\hline L1231 & L. major-like & 0.8 & 1.0 & 0.7 & 1.3 & 6.2 & 1.6 & 22.7 & 22.1 & 23.8 & 9.2 & 5.6 & 1.2 \\
\hline
\end{tabular}

' Results shown express the ratio of cpm bound antibody/cpm bound control; values $>3$ were considered positive and appear in boldface type. 2 Stock identification (classification) also established by isoenzyme and/or schizodeme (kDNA) analyses.

' From the hybridoma clones: M2, IX-2H7-E10; M3, IX-5H9-C10; M7, LXVIII-1D7-B8; M8, LXVIII-4D8-E3; M9, XLV-2B5-H7; P9, CXIII2E9-D12; V1, CLXXVI-3C1-F4; T1, XLVI-5B8-B3; T2, XLVI-4H12-C2; T3, XLVI-SA5-D4; T4, LXVIII-1A4-G1; T8, LXVII-3E12-F8; and T10, XCIV-1H2-A8.

- No significant cross-reactivity was obtained to any of these strains with a large panel of monoclonal antibodies species-specific for $L$. braziliensis or $L$. donovani complex parasites.

study" as a reference strain of " $L$. pifanoi." Characterization of strain L867 by monoclonal antibodies and kDNA analyses is described below.

Reactivity with monoclonal antibodies. The 13 Ecuadorian Leishmania isolates were also characterized by serodeme analysis, using a large panel of species-specific monoclonal antibodies. The specificity of these monoclonal antibodies, which were derived for species complexes of Leishmania, have been described before. ${ }^{11-17}$ As shown in Table 3, some of the monoclonals which bound to reference strains of the $L$. mexicana and $L$. tropica complexes also bound to representative parasite strains from Ecuador. In general, the stocks characterized biochemically as $L$. mexicana reacted weakly with one or both of the monoclonal antibodies designated M7 (LXVIIIID7-B8) and M8 (LXVIII-4D8-E3), which are specific for this parasite species. ${ }^{13}$ The remaining four Ecuadorian isolates (L890, L895, L1226 and L1231), two of which could not be distinguished from the WHO $L$. major reference strains by zymodeme analysis, reacted with monoclonals $\mathrm{T} 1, \mathrm{~T} 2, \mathrm{~T} 3, \mathrm{~T} 4, \mathrm{~T} 8$, and $\mathrm{T} 10$ that were originally produced against parasites in the $L$. major- $L$. tropica complex. ${ }^{15} \mathrm{However}$, these latter four Ecuadorian isolates also reacted with monoclonal P9 (Table 3), which was derived from and is specific for strain L867, described earlier as " $L$. pifanoi." 17 The Old World $L$. major strains did not react with the P9 monoclonal antibody. Similarly, the $L$. mexicana isolates also reacted with the $L$. major-derived monoclonals, but they did not react with the P9 monoclonal. Based on these results, it appears that the $\mathbf{P 9}$ monoclonal antibody is specific for a group of New World parasites which are $L$. major-like.

Schizodeme analysis of $k D N A$. A comparison of kDNA fragment patterns from strains representing selected Leishmania complexes and Ecuadorian parasite isolates was done by schizodeme analysis of endonuclease Msp I, Hinf I (Figure 5), Alu I, Mbo I, Rsa I, and Taq I (Figure 6) digests of kDNAs, fractioned by gradient acrylamide gel electrophoresis. With these digests, sequence microheterogeneity in mini-circle DNA is revealed and can be compared between different parasites. As the degree of heterogeneity within mini-circles varies among species or strains 
of Leishmania, the fingerprint obtained with each of the restriction enzymes is unique for each of these parasites. ${ }^{16,18-19}$ As shown in Figures 5 and 6 , the Ecuadorian isolates which were analyzed in this study can be clustered into two distinct groups of parasites, according to the major sequence classes (minicircle fragments or digests) released by the six restriction endonucleases tested. One of these groups (L890, L895, L1 226 and L1231) had kDNA fragment patterns very similar to those possessed by parasite strain L867. On the basis of their kDNA "fingerprints," the above $L$. major-like isolates are distinct from the Old World L. major strains L581 and L886. They are more closely related to Leishmania strain L186, a parasite which was isolated from a DCL case in Venezuela, and to a group of strains ${ }^{16}$ previously described from Brazil as " $L$. majorlike" (unpublished data).

The second group of Ecuadorian Leishmania isolates (L1225, L1227, L1228, L1233, L1363 and L1364) have very similar kDNA fragment patterns, and are distinct from the $L$. major-like group (Figures 5 and 6). The "fingerprints" of this second group are more like those of the $L$. mexicana reference strain (L577). For this reason we feel that parasites in the latter group represent strains of $L$. mexicana.

\section{DISCUSSION}

Leishmania pifanoi was originally reported from Venezuela ${ }^{20,21}$ where it was associated with a form of diffuse cutaneous leishmaniasis (DCL). Based upon the unusual clinical and epidemiologic features of this disease, the parasite associated with it was initially described as a new species (L. pifanoi). However, more recent molecular studies suggest that DCL in Venezuela is caused by a heterologous group of parasites. Studies comparing isoenzymes, ${ }^{10,} 22$ buoyant densities of both nuclear and kinetoplast DNA, 22, 23 and restriction enzyme fragment patterns, ${ }^{23}$ have shown that several Venezuelan parasite strains tentatively identified as " $L$. pifanoi," including a designated WHO reference strain (MHOM/VE/57/LL1), could not be reliably differentiated from $L$. mexicana. On the other hand, the MHOM/VE/00/L54 strain of "L. pifanoi," which was also isolated from a case of DCL in Venezuela, has been shown to be similar to $L$. amazonensis by monoclonal antibodies, ${ }^{13}$ isoenzyme and kDNA analyses. ${ }^{24}$ Four other more recent isolates from DCL cases in Venezuela were also found to be indistinguishable from $L$. amazonensis by biological criteria and enzyme electrophoresis. ${ }^{25}$ In contrast, the MHOM/VE/00/ L20 strain of " $L$. pifanoi" 26 was distinct from other species of the $L$. mexicana complex by zymodeme analysis (Table 2). This latter strain was also found to be phenotypically similar to reference strains of $L$. major, but it could be differentiated by kDNA restriction enzyme profiles. ${ }^{16}$ The isolate L867, which was used in our study, has also previously been defined as " $L$. pifanoi," based on its characteristic reactivity patterns with specific monoclonal antibodies. ${ }^{17}$ However, results of the present study (Table 3 and Figures $4 \& 5$ ) indicate that the L867 strain from Venezuela as well as the four Ecuadorian strains (L867, L895, L1 226 and L1231) are very similar to the $L$. major reference strains. It also appears that monoclonal P9, which was originally made to L867, is specific for this group of New World $L$. major-like parasites.

The possibility of this latter group of parasites being contaminated with $L$. major seems highly unlikely, given the distinct patterns obtained with monoclonal antibody P9 (Table 3) and kDNA analyses (Figures 4 and 5). Instead, our data confirm a previously reported study, ${ }^{16}$ indicating that $L$. major-like parasites occur naturally in the New World. Work is now in progress to better define the phylogenetic relationship between these parasites and Old World $L$. major strains.

The Venezuelan $L$. major-like parasite, L867, was originally isolated from a case of DCL. It is noteworthy that only one of the four Ecuadorian subjects yielding $L$. major-like parasites had more than 1 ulcerative lesion (Table 1); all were simple cutaneous lesions.

Ten isolates of $L$. mexicana were made from Paute and one from Alausi. Corredor and others ${ }^{27}$ recently reported the isolation of $L$. mexicana from three subjects living in Pueblo Rico, Department of Risaralda, and Samaniego, Department of Narino, in the neighboring country of Colombia. The latter two towns are situated in the western Andean cordillera of Colombia at approximately 1,550 meters elevation; ${ }^{27}$ this mountain range is contiguous with the mountains encompassing Paute and Alausi. The distance between these four towns (approximately $730 \mathrm{~km}$ in a straight line from Pueblo Rico to Paute) suggests that $L$. mexicana may have a fairly wide geographic distribution in the Andean 


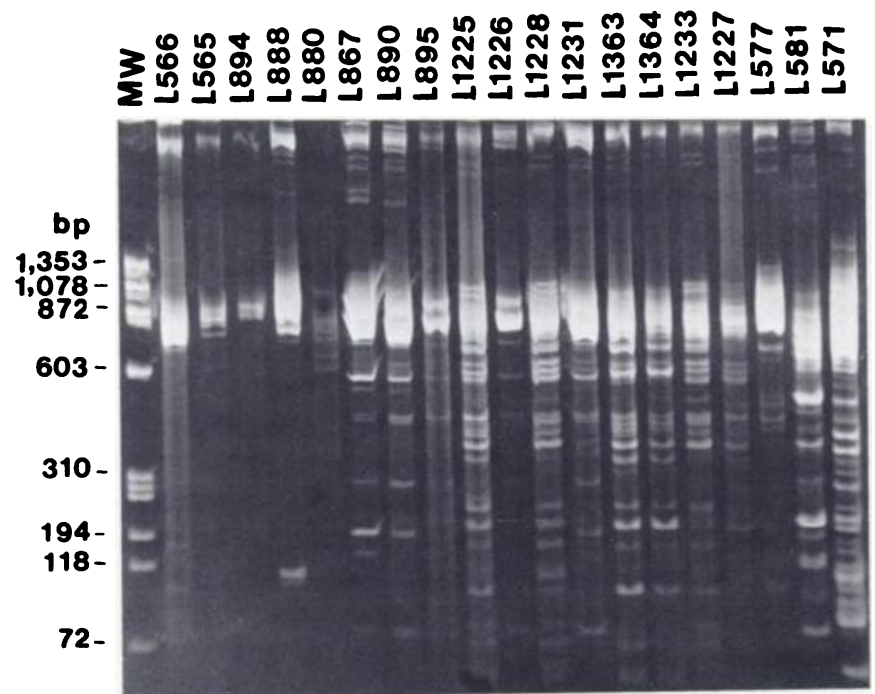

A

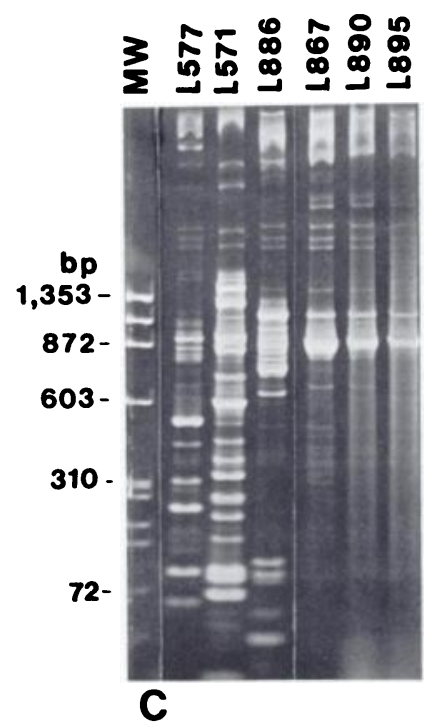

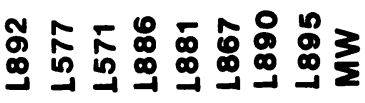

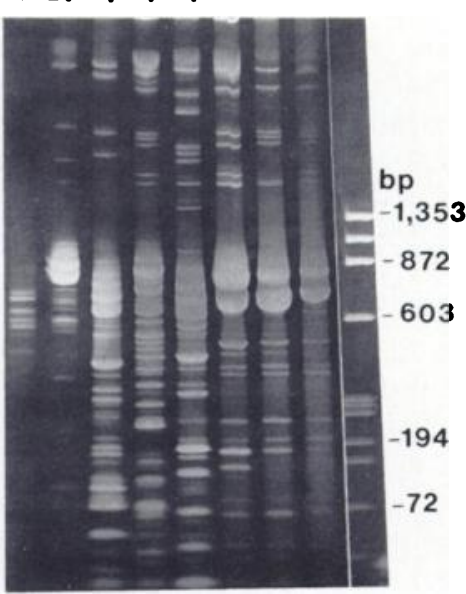

B

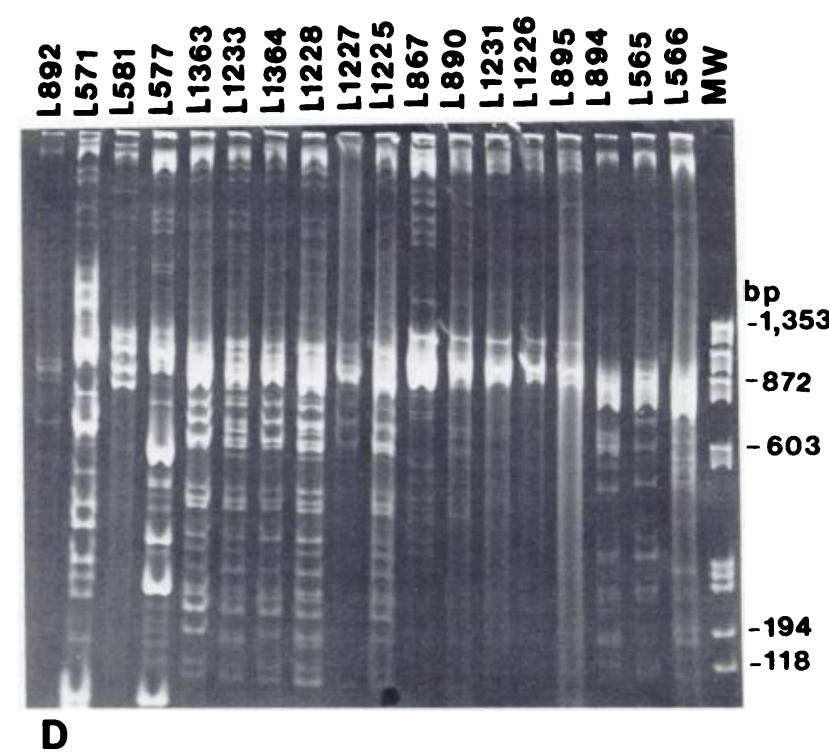

FIOURE 5. Acrylamide gradient (5-12\%) gel electrophoresis comparison of kDNA fragment patterns, generated with the restriction enzymes $M s p I(a, b)$ and $\operatorname{Hinf} I(c, d)$, among selected species complexes of Leishmania and representative parasite strains from Ecuador. The stock codes of the strains studied by kDNA analysis are indicated above the lanes; information on their origin is given in Table 2. The apparent sizes of kDNA fragments are estimated relative to fragments from a Hae III digest of $0 \times 174$ RF DNA and their molecular weights are indicated in base pairs (bp) beside the figures. Undigested kDNA network is visible in the slots at the top of the gels, whereas presumptive maxicircle DNA fragments and minicircle oligomers migrate at $\geq 6 \mathrm{~kb}$ and are visible just below. The linearized minicircles migrate at about $0.8 \mathrm{~kb}$ and, in some lanes, the minicircle digests appear as bands (ladders) between 0.05 and $0.7 \mathrm{~kb}$.

region of northern South America. Because of its altitude and temperate climate, this Andean region is ecologically quite distinct from the warm lowland areas where $L$. mexicana generally occurs in Central America and Mexico. ${ }^{2}$

There are several other unusual features about the Paute focus of cutaneous leishmaniasis. First, active ulcers were observed only in children ( $\mathrm{Ta}$ ble 1), indicating that the disease is highly endemic in the community. Second, many of the 


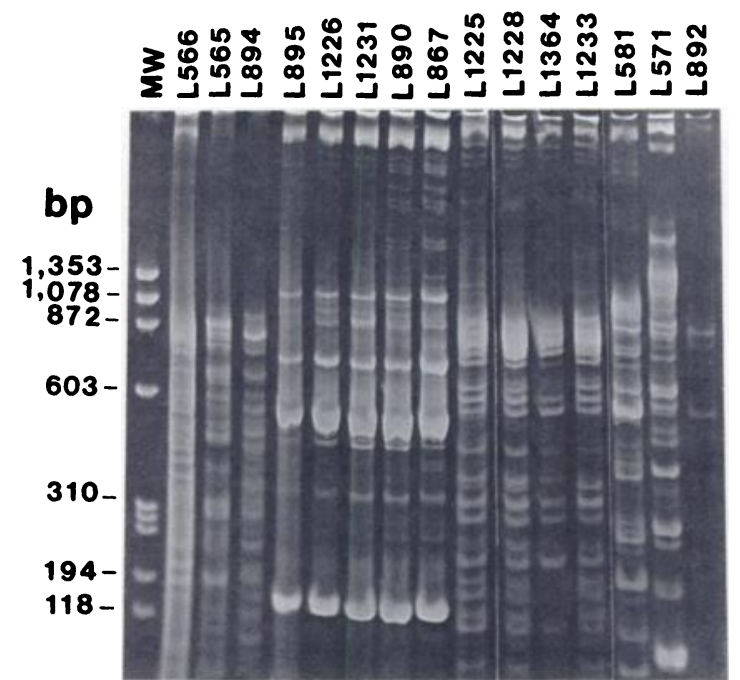

A

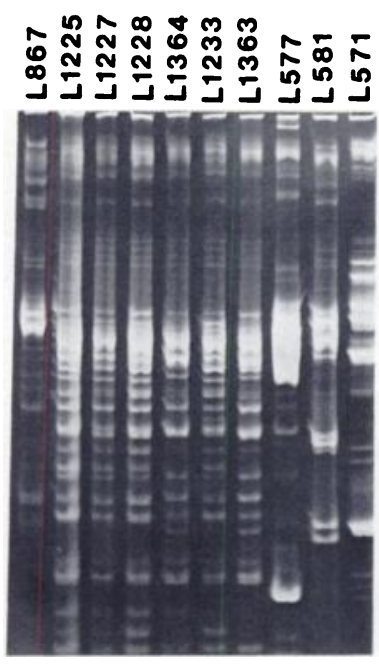

C

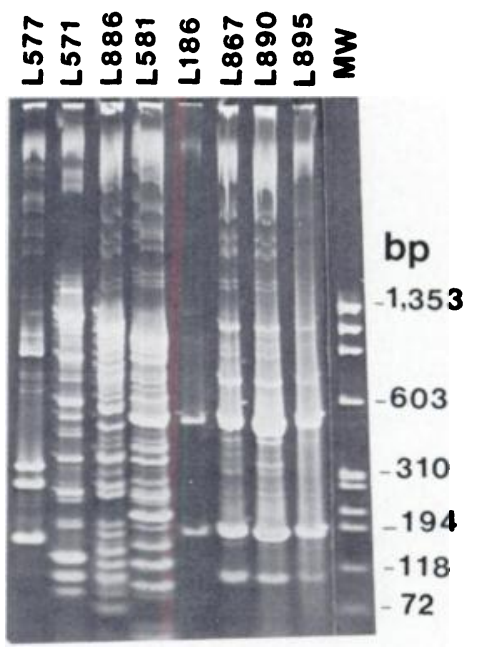

B

Figure 6. Acrylamide gel electrophoresis of $A l u$ I (a, b), Mbo I (c), Rsa I (d) and Taq I (e) digests of kDNAs from selected species complexes of Leishmania and representative parasite strains from Ecuador. DNA was fractioned as described in Fig. 1. The stock codes of the Leishmania strains analyzed are indicated above the lanes, and their origins are shown in Table 2. Molecular weights are indicated in bp beside the figures.

active infections were in infants less than one year of age, implying intradomiciliary transmission. The latter mode of transmission is further suggested by the finding of infected anthropophilic sand flies in rock crevices near human dwellings and by the low night-time temperatures which tend to keep children indoors during the period of maximum sand fly biting activity.

Another interesting aspect of leishmaniasis in
Paute is its clinical similarity to "uta," a cutaneous form of the disease described in Peru. ${ }^{29}$ "Uta" is prevalent among inhabitants of the western slopes and valleys of the Peruvian Andes at elevations between 600 and 3,000 meters above sea level; ${ }^{29}$ this disease is generally thought to be caused by $L$. peruviana. ${ }^{28}$ However, recent molecular studies ${ }^{13,30,31}$ suggest that $L$. peruviana is not a distinct species, but probably a variant of 
$L$. braziliensis. The clinical manifestations of the $L$. mexicana and $L$. major-like infections in Paute (Table 1 and Figures 3A-C) are indistinguishable from case descriptions of "uta."28 Furthermore, the ecology of the Paute area is quite similar to that of the "uta"-endemic region of Peru. 28, 29 These latter findings suggest that "uta" as a clinical entity is not restricted to Peru, and that the disease is probably caused by more than one Leishmania species.

The isolations of $L$. mexicana from a dog and from $L u$. ayacuchensis are noteworthy, since both are new hosts records for this parasite. In Mexico and Central America, forest rodents are thought to be the important reservoir of $L$. mexicana. ${ }^{2,32}$ The isolation of this parasite from a local canine raises the possibility that dogs could be a domestic reservoir of $L$. mexicana in Paute. Interestingly, dogs have long been thought to be the major reservoir of $L$. peruviana (L. braziliensis) and of "uta" in Andean regions of Peru. ${ }^{28,} 32$ Sand fly isolations of $L$. mexicana have been made before from $L u$. olmeca olmeca and $L u$. ylephiletor; ${ }^{2}$ the former species is thought to be the principal vector. Our isolation of this parasite from $\mathrm{Lu}$. ayacuchensis, a man-biting species found around human dwellings in Paute, ${ }^{6}$ adds another potential vector to the list.

Acknowledgments: We wish to thank Dr. Diane McMahon-Pratt, Yale University School of Medicine, for providing the monoclonal antibodies used in this study. We also express appreciation to our collaborators at the Instituto Nacional de Hygiene y Medicina Tropical, Guayaquil, Ecuador.

Financial support: Overseas Scientific Research Program of the Ministry of Education, Science and Culture, Japan (grants 61041059, 62043055 and 63041096); the UNDP/World Bank/WHO Special Programme for Research and Training in Tropical Diseases; the Brazilian Nacional Council of Scientific Development and Technology (CNPq), reference no. 204011/88.4; the National Institutes of Health of the United States (grants AI-21049 and AI-23004); and the MacArthur Foundation (Molecular Parasitology Program).

Authors' addresses: Yoshihisa Hashiguchi, Department of Parasitology, Kochi Medical School, Nankoku, Kochi, 781-52, Japan; Eduardo A. Gomez, Departmento de Parasitologia, Facultad de Medicina, Universidad Catolica, Santiago de Guayaquil, Apartado 4671, Guayaquil, Ecuador; Vicenta V. de Coronel, Departmento de Parasitologia, Instituto Nacional de Higiene y Medicina Tropical, Apartado 3961, Guayaquil, Ecuador; Tatsuyuki Mimori, Department of Parasitic Diseases, Kumamoto University School of Medicine, Kumamoto 860, Japan; Masato Kawabata,
Department of Clinical Pathology, Nihon University School of Medicine, Tokyo 173, Japan; Masato Furuya, Institute for Laboratory Animals, Kochi Medical School, Kochi 781-51, Japan; Shigeo Nonaka, Department of Dermatology, Nagasaki University School of Medicine, Nagasaki 852, Japan; Hiroyuki Takaoka, Division of Medical Zoology, Oita Medical College, Hazama, Oita 879-56, Japan; J. Bruce Alexander, Central Florida Research and Education Center, Sanford, Florida 32771-9608, USA; Aida M. Quizhpe, Hospital Cantonal Paute, Paute, Azuay, Ecuador; Gabriel Grimaldi Jr., Department of Immunology, Instituto Oswaldo Cruz, CEP 21045 Rio de Janeiro, Brazil; Richard D. Kreutzer, Department of Biology, Youngstown State University, Youngstown, Ohio 44555, USA; Robert B. Tesh, Department of Epidemiology \& Public Health, Yale University School of Medicine, New Haven, Connecticut 06510, USA.

\section{REFERENCES}

1. Hashiguchi Y, Gomez EA, 1987. A brief review of leishmaniasis in Ecuador. Hashiguchi Y, ed. Studies on New World leishmaniasis and its transmission, with particular reference to Ecuador: Res Rep Ser No 1. Kochi, Japan: Kyowa Printing Co., 5-32. UI: 8916555

2. Grimaldi G Jr, Tesh RB, McMahon-Pratt D, 1989. A review of the geographic distribution and epidemiology of leishmaniasis in the New World. Am J Trop Med Hyg 41: 687-725. UI: 90265130

3. Mimori T, Grimaldi G Jr, Kreutzer RD, Gomez EA, McMahon-Pratt D, Tesh RB, Hashiguchi $Y, 1989$. Identification, using isoenzyme electrophoresis and monoclonal antibodies, of Leishmania isolated from humans and wild animals of Ecuador. Am J Trop Med Hyg 40: $154-8$.

4. Armijos RX, Chico ME, Cruz ME, Guderian RH, Kreutzer RD, Berman JD, Rogers MD, Grogl M, 1990. Human cutaneous leishmaniasis in Ecuador: identification of parasites by enzyme electrophoresis. Am J Trop Med Hyg 42: 4248. UI 90252908

5. Gomez EA, Coronel VV de, Hashiguchi Y, 1990. Seasonal variation in the infection rates with Leishmania and in the biting activity of the sand fly $\mathrm{Lu}$ ayacuchensis in an Andean leishmaniasisendemic area of Ecuador. Hashiguchi $Y$, ed. Studies on New World Leishmaniasis and its transmission, with particular reference to Ecuador: Res Rep Ser No 2. Kochi, Japan: Kyowa Printing Co., 49-60. UI 8916555

6. Takaoka H, Gomez EA, Alexander JB, Hashiguchi Y, 1990. Natural infections with Leishmania promastigotes in Lutzomyia ayacuchensis (Diptera: Psychodidae) in an Andean focus of Ecuador. J Med Entomol 27: 701-2. UI 90355155

7. Walton BC, Shaw JJ, Lainson R, 1977. Observations on the in vitro cultivation of Leishmania braziliensis. J Parasitol 63: 1118-9. UI 78068440

8. Kreutzer RD, Christensen HA, 1980. Characterization of Leishmania spp. by isozyme electro- 
phoresis. Am J Trop Med Hyg 29: 199-208. UI 80172968

9. Kreutzer RD, Semko ME, Hendricks LD, Wright $\mathrm{N}, 1983$. Identification of Leishmania spp. by multiple isozyme analysis. Am J Trop Med Hyg 32: 703-15. UI 83280475

10. Kreutzer RD, Souraty N, Semko ME, 1987. Biological identities and differences among Leishmania species and sub species. Am J Trop Med Hyg 36: 22-32. UI 87125502

11. Jaffe CL, Bennett E, Grimaldi G Jr, McMahonPratt D, 1984. Production and characterization of species-specific monoclonal antibodies against Leishmania donovani for immunodiagnosis. $J$ Immunol 133: 440-7. UI 84214111

12. Pratt DM, Bennett E, Grimaldi G, Jaffe CL, 1985. Subspecies- and species-specific antigens of leishmania mexicana characterized by monoclonal antibodies. J Immunol 134: 1935-40. UI 85106290

13. Grimaldi G Jr, David JR, McMahon-Pratt D, 1987 Identification and distribution of New World Leishmania species characterized by serodeme analysis using monoclonal antibodies. $\mathrm{Am} \mathrm{J}$ Trop Med Hyg 36: 270-87. UI 87154108

14. McMahon-Pratt D, Bennett E, David JR, 1982. Monoclonal antibodies that distinguish subspecies of Leishmania braziliensis. JImmunol 129. 926-7. UI 82267067

15. Jaffe CL, McMahon-Pratt D, 1983. Monoclonal antibodies specific for Leishmania tropica. I. Characterization of antigens associated with stage- and species-specific determinants. $\mathrm{J}$ Immunol 131: 1987-93. UI 84009127

16. Momen H, Grimaldi G Jr, Pacheco RS, Jaffe CL, McMahon-Pratt D, Marzochi MC, 1985. Brazilian Leishmania stocks phenotypically similar to Leishmania major. Am J Trop Med Hyg 34: 1076-84. UI 86212794

17. Pan AA, McMahon-Pratt D, 1988. Monoclonal antibodies specific for the amastigote stage of Leishmania pifanoi. I. Characterization of antigens associated with stage- and species-specific determinants. J Immunol 140: 2406-14. UI 88170826

18. Lopes UG, Momen H, Grimaldi G Jr, Marzochi MC, Pacheco RS, Morel CM, 1984. Schizodeme and zymodeme characterization of Leishmania in the investigation of foci of visceral and cutaneous leishmaniasis. J Parasitol 70: 89-98. UI 84242239

19. Pacheco RS, Lopes UG, Morel CM, Grimaldi G Jr, Momen H, 1986. Schizodeme analysis of Leishmania isolates and comparison with some phenotypic techniques. Rioux JA, ed. Leishmania taxonomy and phylogeny. Montpellier. IMEEE, 57-65.

20. Medina R, Romero J, 1959. Estudio clinico y parasitologico de una nueva cepa de Leishmania. Arch Venez Patol Parasitol Med 3: 298-326.

21. Medina R, Romero J, 1962. Leishmania pifanoi n. sp. El agent causal de la leishmaniasis tegumentaria diffusa. Arch Venez Med Trop 4; 349353.

22. Chance ML, Gardener PJ, Peters W, 1977. Biochemical taxonomy of Leishmania as an ecological tool. Colloques internationaux du centre de la recherche scientifique, No 239, Ecologie des Leishmanioses. Paris: Editions du CNRS, 5362.

23. Barker DC, Butcher J, 1983. The use of DNA probes in the identification of leishmaniasis: discrimination between isolates of the Leishmania mexicana and $L$. braziliensis complexes. Trans $R$ Soc Trop Med Hyg 77: 285-97. UI 8401866

24. Momen H, Grimaldi G Jr, 1984. On the identity of Leishmania mexicana pifanoi and L. mexicana garnhami [letter] Trans $R$ Soc Trop Med Hyg 78: 701-2. UI 85066787

25. Scorza JV, Delgado O, 1982. Amastigote morphometry and development of 4 isolates of Leishmania mexicana pifanoi from Venezuela in Lutzomyia townsendi. Mem Inst Oswaldo Cruz 77: 217-27. UI 83191567

26. Miles MA, Povoa MM, de Souza AA, Lainson R, Shaw JJ, 1980. Some methods for the enzymatic characterization of Latin-American Leishmania with particular reference to Leishmania mexicana amazonensis and subspecies of Leishmania hertigi. Trans $R$ Soc Trop Med Hyg 74: 243-52. UI 80214865

27. Corredor A, Kreutzer RD, Tesh RB, Boshell J, Palau MT, Caceres E, Duque S, Pelaez D, Rodriguez G, Nichols S, and others, 1990. Distribution and etiology of leishmaniasis in Columbia. Am J Trop Med Hyg 42: 206-14. UI 90196458

28. Lumbreras H, Guerra $H, 1985$. Leishmania in Peru. Chang K-P, Bray RS, eds. Leishmaniasis Amsterdam: Elsevier, 297-311.

29. Herrer A, 1957. Verruga y uta en el valle de Huaillacayan (Depto. de Ancash). I. Determinacion de los limites altitudinales de la zona endemica y de la incidencia de ambas enfermedades. Rev Med Exp 11: 40-49.

30. Romero GG, Arana M, Lopez M, Montoya I, Bohl R, Campos M, Arevalo J, Llanos A, 1987. Characterization of Leishmania species from Peru. Trans $R$ Soc Trop Med Hyg 81: 14-24. UI 88178899

31. Lopez M, Montoya $Y$, Arana M, Cruzalegui F, Braga J, Llanos-Cuentas A, Romero G, Arevalo J, 1988. The use of nonradioactive DNA Probes for the characterization of Leishmania isolates from Peru. Am J Trop Med Hyg 38: 308-314. UI 88181354

32. Lainson R, Shaw JJ, 1987. Evolution, classification and geographical distribution. Peters $W$, Killick-Kendrick R, eds. The Leishmaniases in Biology and Medicine, Biology and Epidemiology. London: Academic Press, Vol 1, 1-120. 